Rocznik Przekładoznawczy
Studia nad teoria, praktyką i dydaktyka przekładu

Łukasz Jasiński

Bydgoszcz

\title{
TRANSLATORY ELEKTRONICZNE W PROCESIE TRANSLACJI POMOC CZY PRZESZKODA?
}

\begin{abstract}
Zarys treści: Autor przeprowadza analizę tłumaczeń krótkich tekstów z języka polskiego na niemiecki i z języka niemieckiego na polski dokonanych przez najpopularniejszy obecnie na rynku elektroniczny translator "Deutsch Translator 2" firmy Techland. Badaniu poddane zostały trzy krótkie teksty o tematyce komputerowej, sportowej oraz tekst zawierający związki frazeologiczne. Na podstawie analizy tłumaczeń przykładowych tekstów wskazane zostały liczne błędy występujące w przekładzie dokonanym przez program komputerowy. W konkluzji autor wskazuje na czynniki, które jego zdaniem sprawiają, iż programy tłumaczące nie staną się w najbliższym czasie konkurencją dla „żywych” tłumaczy, a powinny być raczej postrzegane jako pomoc w pracy tłumacza.
\end{abstract}

Słowa kluczowe: tłumaczenie, translator elektroniczny, badania translatorów elektronicznych

Komputer jest bez wątpienia jednym z najważniejszych wynalazków XX Nwieku. Zrewolucjonizował on niemalże każdą dyscyplinę nauki - w tym również nauki humanistyczne (por. Duch 1997: 39-49). Podczas gdy w pierwszej fazie poprzedniego stulecia komputer był używany przede wszystkim jako rozbudowana maszyna do pisania, to dziś - dzięki rozwojowi hipertekstu oraz rozpowszechnieniu Internetu - stanowi nieodzowne wręcz narzędzie dla każdego filologa. Digitalizacja tekstów, powstanie hipertekstu ${ }^{1}$ oraz ich publikacja w Internecie lub rozpowszechnianie na innych nośnikach danych umożliwiają nie tylko szybsze dotarcie do poszczególnych utworów literackich, artykułów naukowych itp., lecz pozwalają również na błyskawiczne odnalezienie w danym

${ }^{1}$ Definicję oraz historię powstania hipertekstu można znaleźć w: netz literatur projekt, Sabrina Ortmann, Berlin 2001, s. 21-24. 
tekście szukanego przez nas konkretnego jego fragmentu oraz jego dowolną edycję i kopiowanie (w głównej mierze dzięki operacji copy and paste).

Od kilku lat sukcesywnie wzrasta liczba elektronicznych wersji słowników wydawanych na CD-ROM-ach - zarówno jednojęzycznych (najpopularniejsze jednojęzyczne słowniki języka niemieckiego dostępne w wersji elektronicznej to: „DUDEN - Deutsches Universalwörterbuch”, „Wahrig Digital” oraz „Langenscheidt e-Großwörterbuch Deutsch als Fremdsprache"), jak i dwujęzycznych (np. „Słownik polsko-niemiecki i niemiecko-polski Langenscheidt”, ,Leksykonia: Słowniki niemiecko-polskie i polsko-niemieckie naukowo-techniczne, specjalistyczne i ogólne"). Coraz szybciej wzrasta również liczba słowników on-line, dostępnych $\mathrm{w}$ Internecie. Jednym $\mathrm{z}$ najpopularniejszych słowników polsko-niemieckich dostępnych $w$ Internecie jest słownik oferowany przez internetowy portal Onet.pl (http://portalwiedzy.onet.- pl/tlumacz.html). Elektroniczne wersje słowników jedno- oraz dwujęzycznych umożliwiają nie tylko sprawniejsze i skuteczniejsze wyszukiwanie poszczególnych haseł, lecz także ułatwiają w znacznej mierze wszelkie badania leksykograficzne. Korzystając z elektronicznej wersji słownika, możemy w kilka sekund znaleźć wszystkie hasła z szukanym przez nas kwalifikatorem.

O wzroście znaczenia słowników komputerowych, opartych na strukturze hipertekstu, dla nauk filologicznych może świadczyć fakt, iż w ostatnich latach coraz większa liczba językoznawców (m.in. Ulrike Haß-Zumkehr 2001, Annette Klosa 2001) zajmuje się badaniami naukowymi, których przedmiotem są właśnie elektroniczne wersje słowników. Komputery jako pomoc w pracy filologa są coraz częściej przedmiotem badań również w Polsce, czego dowodem jest wzrastająca liczba publikacji poświęconych tej tematyce, jak np. wydana w 2004 r. książka Komputer w pracy tlumacza, autorstwa M. Ecksteina i R. Sosnowskiego.

W ostatnim czasie pojawiło się na rynku wiele programów, które można określić mianem elektronicznych translatorów, czyli programów wykonujących thumaczenie maszynowe. Programy te różnią się tym od tradycyjnych elektronicznych słowników, że - przynajmniej według zapewnień ich autorów - tłumaczą automatycznie nie tylko pojedyncze słowa, lecz całe teksty. Wprawdzie pierwsze projekty mechanicznego thumaczenia tekstów przez komputer z jednego języka na inny pojawiły się już w latach 50 . XX. wieku, to dopiero od niedawna mamy do czynienia $\mathrm{z}$ programami, przez niektórych uznawanymi za wartościowe narzędzie, które ma za zadanie ułatwić pracę tłumacza. Rozważa- 
nia dotyczące programów do thumaczenia maszynowego tekstu ${ }^{2}$ znajdują się jednak wciąż we wstępnej fazie (por. Pisarska, Tomaszkiewicz 1996).

$\mathrm{Na}$ czym polega działanie elektronicznych translatorów, czyli programów do tłumaczenia tekstów z języka obcego na język polski i odwrotnie, spróbuję pokazać w krótkim zarysie na przykładzie najpopularniejszego i najbardziej rozbudowanego na polskim rynku programu, który dokonuje przekładu z języka niemieckiego na język polski i odwrotnie: „Deutsch Translator 2”, wyprodukowanego przez firmę Techland.

„Deutsch Translator 2" wykorzystuje ogromną bazę słownikową - ok. 500 tysięcy tłumaczeń, 245 tysięcy fraz i 7,8 miliona form fleksyjnych. Autorzy zapewniają, iż dzięki mechanizmom analizującym i tłumaczącym konstrukcję gramatyczną zdań, opartym na najnowszych światowych osiągnięciach lingwistyki komputerowej, „Deutsch Translator 2” sam dobiera odpowiednią część mowy, końcówkę oraz poprawny szyk wyrazów w zdaniu. Użytkownik może wybrać jeden z 30 profili kontekstowych tekstu, np.: archeologiczny, architektoniczny, biblijny, filozoficzny, handlowy, językowy, matematyczny, poetycki, prawniczy, sportowy, techniczny, wulgarny, żartobliwy, lub dowolnie je ze sobą łączyć. Ma to na celu podniesienie jakości tłumaczenia tekstu z danej dziedziny - w wypadku, gdy dane słowo ma kilka znaczeń, w zależności od profilu kontekstowego, który wybraliśmy, program powinien wybrać odpowiedni ekwiwalent dla danej dziedziny.

Użytkownik ma również możliwość ustawienia sposobu tłumaczenia zaimków osobowych dla danego tekstu, np. dla niemieckiego zaimka osobowego „ich” możemy wybrać polski zaimek osobowy ,ja” zarówno w rodzaju męskim, jak i żeńskim, dla niemieckiego zaimka osobowego „Sie” polskie „Pan”, „Pani”, „Panowie”, „Panie” lub „Państwo”.

Ma to swoje odzwierciedlenie w przykładowym zdaniu:

Ich bin zur Schule gegangen.

W zależności od tego, czy w zakładce „Tłumaczenie zaimków” zaznaczymy, że zaimek osobowy ,ich” ma być tłumaczony jako ,ja” rodzaju żeńskiego, czy jednak ,ja” rodzaju męskiego, możemy otrzymać albo zdanie:

Poszłam do szkoły,

w którym podmiot jest rodzaju żeńskiego, co widoczne jest w odpowiedniej formie fleksyjnej czasownika, właściwej dla rodzaju żeńskiego (poszłam), albo zdanie:

Poszedtem do szkoty,

2 Szczegółowe rozróżnienie i charakterystykę tłumaczenia maszynowego można znaleźć w: Tezaurus terminologii translatorycznej, red. J. Lukaszyn, Warszawa 1993, s. 359-361. 
w którym podmiotem jest ,ja” w rodzaju męskim.

Opcja ta ma bardzo istotne znaczenie w thumaczeniu z języka niemieckiego na język polski, gdyż w języku polskim - inaczej niż w niemieckim - czasowniki odmieniają się nie tylko przez osobę i liczbę, lecz również często przyjmują formę fleksyjną odpowiednią dla rodzaju podmiotu (żeńskiego lub męskiego).

Program oferuje również dwa tryby thumaczenia: automatyczny i ręczny. W trybie automatycznym tekst tłumaczony jest $\mathrm{w}$ całości przez komputer. Wybór trybu thumaczenia ręcznego pozwala nam na ingerencje w thumaczony tekst. Możemy bowiem na bieżąco - po każdym przetłumaczonym przez komputer pojedynczym zdaniu - dokonywać w nim dowolnych poprawek. Zmiana thumaczenia jednego słowa nie powoduje zmiany thumaczenia pozostałej części zdania. Użytkownik może więc sam decydować, jaki ekwiwalent danego słowa $\mathrm{w}$ drugim języku komputer powinien wybrać.

Jedno z haseł reklamowych programu „Deutsch Translator 2” brzmi: „Nowa jakość thumaczenia". Wynikiem thumaczenia tego zdania w trybie automatycznym jest:

Eine neue Beschaffenheit der Übersetzung.

Poddając to zdanie thumaczeniu w trybie ręcznym, możemy zmienić według uznania np. tłumaczenie słowa jakość z Beschaffenheit (które wg „Niemiecko-polskiego słownika Langenscheidt" oznacza właściwość, własność, stan, ale nie jakość) na inny, naszym zdaniem będące bardziej odpowiednim w tym kontekście. Zaznaczając kursorem w tekście źródłowym słowo Beschaffenhei, w rubryce „Korekta” pojawiają się możliwe tłumaczenia tego słowa w języku polskim: Beschaffenheit, Güte, Qualität. Użytkownik jednym kliknięciem myszką może wybrać z tych trzech słów jedno, które według niego byłoby najlepszym jego odpowiednikiem w języku polskim. W ten sposób możemy uzyskać zdanie Eine neue Qualität der Übersetzung.

Aby poddać program „Deutsch Translator 2” gruntowniejszemu testowi, zobaczmy, jak radzi on sobie z trzema tekstami o różnych profilach: sportowym, komputerowym, oraz z tekstem zawierającym kilka związków frazeologicznych.

\section{Tekst o profilu sportowym}

Po automatycznej translacji następujących zdań:

Po dtugim dośrodkowaniu Ballacka, gola glowa strzelit Makaay. Dzięki temu zwycięstwu Bayern powiększyt przewage w tabeli Bundesligi nad rywalami o 3 punkty. 
z języka polskiego na język niemiecki otrzymujemy następujący tekst wygenerowany przez program „Deutsch Translator 2”:

Nach dem langen Demonstrieren Ballacka, Toren einen Kopf schoss Makaay. Dank diesem einem Sieg Bayern eine Führung vergrößerte in der Tabelle Bundesligi über die Konkurrenten über 3 Punkten.

Mimo dość rozbudowanego słownika programu oraz faktu, iż w opcjach programu zaznaczono odpowiedni profil thumaczenia (język sportowy), program nie potrafił odpowiednio przetłumaczyć ani słowa dośrodkowanie, zastępując je zupełnie bezpodstawnie słowem Demonstrieren, ani frazy strzelić gola głową (Toren einen Kopf schießen zamiast np. ein Kopfballtor machen). Należy zwrócić uwagę również na niepotrzebny rodzajnik nieokreślony einem we frazie Dank diesem einem Sieg oraz użycie błędnego w tym kontekście przyimka über zamiast um oraz rzeczownika Punkte w złym przypadku we frazie über 3 Punkten. Bez pomocy użytkownika program nie radzi sobie również z thumaczeniem, a właściwie zmienianiem formy nazw własnych, np. słowa Bundesliga.

Kolejne błędy, które możemy zaobserwować w tekście docelowym, to złe umiejscowienie orzeczenia vergrößerte $\mathrm{w}$ zdaniu oraz użycie rodzajnika nieokreślonego eine przed rzeczownikiem Führung.

\section{Tekst o tematyce komputerowej}

Badaniu został poddany krótki tekst związany z tematyką komputerową o następującej treści:

Entpacken Sie die Datei in ein Verzeichnis. Klicken Sie dann mit der linken Maustaste auf die Datei "setup", um die Installation zu starten. Mit einem Doppelklick auf das Icon "DT2" kann dann die Applikation gestartet werden.

W wyniku procesu translacji tekstu wykonanej przez komputer, otrzymujemy tekst o następującej treści:

Entpacken państwo plik do spisu. Państwo klikaja potem z lewym klawiszem myszy na plik „setup”, aby wystartować instalacje. Z jednym Kliknij podwójnie myszka na ikonę "DT2" może zostać wystartowany potem aplikacja.

Również tym razem baza leksykalna słownika programu okazała się zbyt mała, aby przetłumaczyć jeden z podstawowych terminów języka komputerowego Entpacken, którego odpowiednikiem w języku polskim jest słowo rozpakow(yw)ać. Komputer również błędnie w tym kontekście przetłumaczył słowo Verzeichnis jako spis. Verzeichnis w języku komputerowym oznacza przede wszystkim katalog i tak też słowo to powinno zostać przetłumaczone w tym wypadku. W słowniku programu znajdujemy aż pięć polskich odpowiedników 
słowa Verzeichnis - żadnym z nich nie jest jednak katalog (są to natomiast następujące słowa: spis, informator, lista, ewidencja, wykaz).

Kolejny problem, który dla programu „Deutsch Translator 2” okazał się zbyt trudny, to fraza Klicken Sie dann mit der linken Maustaste [...]. Translator przetłumaczył tę frazę słowo po słowie, w wyniku czego otrzymaliśmy: Państwo klikają potem z lewym klawiszem myszy [...]. Mit der linken Maustaste nie może być w tym wypadku thumaczone jako związek przyimka i rzeczownika, lecz musi zostać w języku polskim zastąpione jedynie związkiem przymiotnika i rzeczownika użytych w narzędniku. Taki sam błąd komputer popełnił w kolejnym zdaniu, niewłaściwie tłumacząc frazę Mit einem Doppelklick [...].

O ile przekład drugiego zdania tego krótkiego tekstu można uznać za mniej lub bardziej udany, to ostatnie zdanie (Mit einem Doppelklick auf das Icon „DT2” kann dann die Applikation gestartet werden). zostało przethumaczone dużo gorzej. Program nie potrafił przetłumaczyć słowa Doppelklick, zastępując je zwrotem Kliknij podwójnie myszką, a nie właściwym podwójne kliknięcie myszką. Wynika to bowiem $\mathrm{z}$ faktu, iż $\mathrm{w}$ słowniku programu występuje wprawdzie czasownik doppelklicken (klikać podwójnie myszką), nie ma w nim natomiast rzeczownika Doppelklick. Podczas przekładu drugiej części zdania kann dann die Applikation gestartet werden komputer zachował wprawdzie $\mathrm{w}$ tekście wynikowym stronę bierną (konstrukcja kann gestartet werden została prawidłowo przetłumaczona jako może zostać wystartowany, przy czym można w tym wypadku zastanawiać się, czy lepszym odpowiednikiem czasownika starten w tym wypadku nie byłoby słowo uruchamiać zamiast startować), lecz zmienił błędnie przypadek thumaczonego rzeczownika Applikation z mianownika na celownik (aplikacją zamiast aplikacja).

\section{Tekst zawierający wyrażenia idiomatyczne}

Zadaniem programu „Deutsch Translator 2” było przetłumaczenie następującego tekstu, zawierającego kilka wyrażeń idiomatycznych:

Martin schoss einen Bock, indem er seinen Lehrer beleidigt hatte. Danach lief er Hals über Kopf nach Hause. Er fasste sich ein Herz und erzählte seiner Mutter die ganze Geschichte. Die Mutter sagte zu ihm: „Jetzt hast du wirklich eine harte Nuss zu knacken!".

W efekcie otrzymujemy tekst wynikowy o następującej treści:

Marcin popetnit bład, on obrazit jego nauczyciela. On biegat po tym na teb, na szyje do domu. On zebrat się na odwage $i$ cata historia opowiedziata jego 
matkę. Matka powiedziała na niego: „Masz teraz do trzaśnięcia rzeczywiście twardy orzech!"

Pierwszy frazeologizm w tekście (einen Bock schießen) został przez komputer przetłumaczony właściwie. Jednak w thumaczeniu zdania okolicznikowego sposobu (niem. Modalsatz) indem er seinen Lehrer beleidigt hatte brakuje $\mathrm{w}$ tekście docelowym imiesłowu czynnego (w tym wypadku: obrażając), którego zazwyczaj używa się, tłumacząc zdania z konstrukcją indem na język polski. Translator utworzył z tego zdania dwa zdania równorzędne: Marcin popełnił błąd, on obraził jego nauczyciela. $W$ tym miejscu należy również podkreślić użycie przez program niewłaściwego zaimka dzierżawczego jego, a nie swego.

W drugim zdaniu związek frazeologiczny został również prawidłowo przethumaczony (Hals über Kopf laufen), jednak niedokonana forma czasownika biegać wydaje się w tym konkretnym przykładzie nie na miejscu. Problem ten wynika $\mathrm{z}$ braku $\mathrm{w}$ języku niemieckim podziału czasowników na dokonane $\mathrm{i}$ niedokonane (aspekt). Program zdaje się decydować dowolnie, czy w thumaczeniu na język polski użyje czasownika w aspekcie dokonanym, czy też niedokonanym, zarówno bowiem przykładowe zdanie Er ging nach Hause, jak i Er ist nach Hause gegangen. po przetłumaczeniu przez DT2 na język polski brzmi On poszedł do domu.

W zdaniu trzecim (Er fasste sich ein Herz und erzählte seiner Mutter die ganze Geschichte) mamy do czynienia po raz z kolejny z błędnym przyporządkowaniem poszczególnym rzeczownikom właściwych przypadków. To przecież nie historia opowiedziała matkę, a on, czyli Martin, opowiedział historię matce.

W ostatnim zdaniu po raz kolejny komputer użył niewłaściwego przyimka (na zamiast do). Poza tym w języku polskim odpowiednikiem frazeologizmu użytego w ostatnim zdaniu eine harte Nuss zu knacken haben jest wyrażenie mieć twardy orzech do zgryzienia, a nie do trzaśnięcia.

$\mathrm{Z}$ wyjątkiem ostatniego frazeologizmu „Deutsch Translator 2" dobrze poradził sobie z thumaczeniem wyrażeń idiomatycznych na język polski.

Jeśli jednak rozszerzymy np. związek frazeologiczny z pierwszego zdania (einen Bock schießen) o przymiotnik schwer i zlecimy programowi „Deutsch Translator 2" przetlumaczenie nowo powstałego zdania

Er schoss einen schweren Bock, indem er seinen Lehrer beleidigt hatte, otrzymamy następujące zdanie w języku polskim:

On strzelit ciężkiego kozła, on obraził jego nauczyciela.

Jak widać, twórcy programu nie przewidzieli możliwości rozbudowywania związków frazeologicznych o nowe elementy.

Analiza jedynie trzech tłumaczeń krótkich tekstów, wykonanych przez translator elektroniczny „Deutsch Translator 2”, pokazuje, iż program ten ma spore problemy zarówno z tłumaczeniem poszczególnych słów oraz fraz z języ- 
ka polskiego na niemiecki i odwrotnie, mimo iż słownik programu składa się z ok. 500 tys. haseł. Translator w wielu przypadkach albo nie potrafi wybrać odpowiedniego słowa w języku docelowym (np. spis zamiast katalog), albo w ogóle słowo do przetłumaczenia nie występuje w bazie słownikowej programu (np. entpacken czy Doppelklick). Poza tym program nie zawsze używa rzeczowników w odpowiednich przypadkach (np. cała historia opowiedziała matkę, zamiast opowiedział całą historię matce), ma problemy $\mathrm{z}$ thumaczeniami czasowników dokonanych i niedokonanych, a także niejednokrotnie używa złych przyimków (np. über drei Punkte, a nie um drei Punkte).

Wynik badania jakości thumaczeń dokonanych przez „Deutsch Translator 2", uznawanego za jeden z najlepszych translatorów elektronicznych na polskim rynku, pokazuje, iż tego typu programy nie stanowią obecnie żadnego zagrożenia dla „żywych" tłumaczy. Programy tego typu mogą jedynie pomóc osobom nieznającym danego języka powierzchownie zorientować się w treści tekstu. Mimo wielu niedoskonałości elektroniczne translatory mogą być jednak dość pomocnym narzędziem tłumacza, chociażby dzięki zawartemu w nich dość rozbudowanemu słownikowi, i przyspieszyć dzięki temu jego pracę. Użytkownik może bowiem m.in. samemu dodawać nowe słowa do słownika programu, przypisując im odpowiednie kwalifikatory, i zwiększyć w ten sposób skuteczność thumaczeń wykonywanych przez „Deutsch Translator 2”.

Mimo że prawdopodobnie już w niedalekiej przyszłości będą pojawiać się programy, których baza słownikowa będzie dużo większa niż oferowana przez istniejące obecnie programy, to nie będą one wciąż stanowić poważniejszej konkurencji dla tłumaczy-ludzi. Od thumacza wymaga się bowiem przecież nie tylko znajomości języka, lecz również wiedzy o specyfice wymiaru sprawiedliwości w obu krajach, o systemach szkolnictwa, terminologii prawniczej. Połączenie takiej wiedzy ze słownikiem dwujęzycznym w jednym programie komputerowym wydaje się w dzisiejszych czasach - patrząc na problemy, z jakimi obecnie nie radzą sobie translatory elektroniczne - raczej niemożliwe.

\section{Literatura}

Duch, W. 1997, Historia Internetu, Poznań.

Duden, Deutsches Universalwörterbuch A-Z, CD-ROM Ausgabe.

Eckstein M., Sosnowski R. 2004, Komputer w pracy tlumacza. Praktyczny poradnik, Kraków.

Haß-Zumkehr, U. 2001, Zur Mikrostruktur im Hypertext-Wörterbuch, [w:] Chancen und Perspektiven computergestützer Lexikographie. Hypertext, In- 
ternet und SGML/XML für die Produktion und Publikation digitaler Wörterbücher, red. I. Lemberg B., Schröder, A. Storrer, Tübingen, s. 103-115.

Klosa, A. 2001, Qualitätskriterien der CD-ROM-Publikationen von Wörterbüchern, [w:] Chancen und Perspektiven computergestützer Lexikographie. Hypertext, Internet und SGML/XML für die Produktion und Publikation digitaler Wörterbücher, red. I. Lemberg, B. Schröder, A. Storrer, Tübingen, s. 93-101.

Langenscheidt - Großwörterbuch Deutsch als Fremdsprache 4.0.

Leksykonia: Słowniki niemiecko-polskie i polsko-niemieckie naukowo-techniczne, specjalistyczne i ogólne, CD-ROM.

Onet.pl: Portal wiedzy - Tłumacz, http://portalwiedzy.onet.pl/tlumacz.html.

Ortmann, S. 2001, netz literatur projekt, Berlin, s. 21-24.

Pisarska, A., Tomaszkiewicz, T. 1996, Współczesne tendencje przekładoznawcze, Poznań, s. 66-73.

Słownik polsko-niemiecki i niemiecko-polski Langenscheidt, CD-ROM.

Tezaurus terminologii translatorycznej 1993, red. J. Lukaszyn, Warszawa, s. 359-361.

Wahrig.digital, Deutsches Wörterbuch.

\section{Electronic translators in the process of translation. Help or an obstacle?}

Summary

This article is an attempt aimed at the analysis how computer software, called electronic translators, deals with translation of texts from Polish into German and from German into Polish. For the present analysis the author has used "Deutsch Translator 2" which is the most popular translating software on the Polish market. The article shows results of conducted analysis of electronic translation of three kinds of texts: text on sports, text on computers and text including certain phraseological units. On the basis of target texts the author shows numerous mistakes in the translations made by the computer software and in the conclusion he indicates factors which result in the fact that electronic translators will not become a serious competitor for "living" translators in the future. He presents conclusions regarding why this kind of software should be perceived as helpful in the translator's work.

Keywords: translation, electronic translator, electronic translator research 